\title{
Pemahaman dan Penghayatan Peserta Didik tentang Ibadah dalam Pembelajaran Fiqih di MI Manafiul Ulum Gebog Kudus
}

\author{
Ashif Az Zafi \\ Institut Agama Islam negeri (IAIN) Kudus \\ Jl. Conge Ngembal Rejo, Kudus, Jawa Tengah \\ ashifazzafi@iainkudus.ac.id
}

Received: Jan 23, 2020

Revised: March 12, 2020

Accepted: April 10, 2020

\begin{abstract}
The purpose of this research was to find out what are the practices of students' worship and how students understand and appreciate their worship. This research was a field research with qualitative data analysis. Data analysis was carried out through some steps, namely data collection, data reduction, data presentation and conclusion drawing. Test the validity of the data using triangulation. The results of this study showed that the worship activities taught and accustomed to students were prayer, fasting, daily prayer, reading and memorizing the Qur'an. The students understood the laws of worship such as compulsory, sunna, sin, reward, heaven and hell. However, they do not yet understand about the purpose and benefits of worship that it does. The practice of worship of students was classified as obedient and has become a daily habit. This shows that the practice of students' worship has become a personality (being / moral action) but is still weak in understanding (moral knowledge) and has not yet reached awareness (moral feelings).
\end{abstract}

Keywords: understanding of worship, appreciation of worship, value education, Madrasah Ibtidaiyah

\begin{abstract}
Abstrak
Tujuan dilakukan penelitian ini adalah untuk mengetahui apa saja pengamalan ibadah peserta didik dan bagaimana pemahaman serta penghayatan peserta didik tentang ibadah yang dilaksanakannya. Penelitian ini merupakan penelitian lapangan dengan analisis data kualitatif. Analisis data dengan langkah pengumpulan data, reduksi data, penyajian data dan penarikan kesimpulan. Uji keabsahan datanya menggunakan triangulasi. Hasil dari penelitian ini adalah ibadah yang diajarkan dan dibiasakan kepada peserta didik adalah salat, puasa, doa harian, membaca dan menghafal Al Quran. Pemahaman peserta didik tentang pengamalan ibadah sudah paham mengenai hukum ibadah seperti wajib, sunah, dosa, pahala, surga dan neraka. Namun peserta didik belum memahami tentang tujuan dan manfaat ibadah yang dilaksanakannya. Pengamalan ibadah peserta didik tergolong taat dan sudah menjadi kebiasaan sehari-hari. Ini menunjukkan bahwa pengamalan ibadah peserta didik sudah menjadi kepribadian (being/tindakan moral) namun masih lemah dalam pemahaman (pengetahuan moral) dan belum mencapai kesadaran (perasaan moral).
\end{abstract}

Kata Kunci: pemahaman ibadah, penghayatan ibadah, pendidikan nilai, Madrasah Ibtidaiyah 


\section{Pendahuluan}

Era disrupsi menimbulakan positive effect dan negative effect. Ciri dari era disrupsi adalah cepatnya informasi didapat oleh semua kalangan, tidak terkecuali oleh anak usia sekolah dasar. Dampak dari cepatnya pertukaran informasi terhadap anak usia sekolah dasar adalah mereka akan semakin banyak mendpaatkan infromasi tetapi kurang bisa dalam melakukan filter informasi tersebut. Permasalahan ini berusaha diselesaikan oleh sekolah-sekolah Islam dengan memberikan materi agama (akhlak dan ibadah). Sehingga orang tua banyak memilih sekolah-sekolah Islam atau madrasah mengedepankan materi agama. Sekolah Islam dan Madrasahpun juga berbenah diri dalam memberikan materi agama agar dapat membentuk karakter peserta didiknya. Hal terseut sesuai dengan sasaran dan tujuan utama pendidikan.

Pendidikan merupakan bidang yang sangat penting bagi kehidupan manusia. Kemajuan suatu bangsa atau negara ditentukan oleh kemajuan pendidikannya. Pendidikan berperan dalam mengembangkan potensi manusia. Manusia yang beradab yaitu manusia yang memiliki kualitas ilmu pengetahuan dan beriman kepada Tuhan Yang Maha Esa. Hal itu sesuai dengan Undang-undang Sistem Pendidikan Nasional No. 20 Tahun 2003 yang mengatakan bahwa "Pendidikan Nasional berfungsi mengembangkan kemampuan dan membentuk watak serta peradaban bangsa yang bermartabat dalam rangka mencerdaskan kehidupan bangsa, bertujuan untuk berkembangnya potensi peserta didik agar menjadi manusia yang beriman dan bertaqwa kepada Tuhan yang Maha Esa, berakhlak mulia, sehat, berilmu, cakap, kreatif, mandiri, dan menjadi warga negara yang demokratis serta bertanggung jawab." Pendidikan persekolahan merupakan kelanjutan dari pendidikan yang berlangsing di dalam keluarga dan masyarakat. Sekolah merupakan lembaga formal sebagai tempat proses sosialisasi anak.
Proses tersebut akan mempengaruhi pribadi anak dan perkembangan sosialnya ${ }^{1}$.

Pendidikan adalah kebutuhan setiap individu dan kebutuhan masyarakat. Kebutuhan akan pendidikan tidak dapat tergantikan dengan yang lain. Pendidikan digunakan sebagai pengembangan kualitas, pontensi dan bakat diri pada setiap manusia. Pendidikan membentuk individu menjadi pribadi yang utuh. Menjadi manusia yang tidak mengetahui menjadi mengetahui, yang bodoh menjadi pintar, yang tidak paham menjadi paham. Pendidikan membentuk manusia memiliki jasmani dan rohani yang paripurna. Pendidikan bertujuan untuk mengembangkan dua aspek penting yang ada di dalam diri manusia. Kedua aspek itu adalah aspek rohani dan pendidikan bersifat lahiriyah. Pendidikan yang ditujukan untuk mengembangkan aspek rohani merujuk kepada kualitas kepribadian, akhlak, perilaku, dan karakter peserta didik ${ }^{2}$. Pendidikan yang ditujukan untuk mengembangkan aspek jasmani, seperti keterampilan, kesehatan, cakap, kreatif, inovatif. Pengembangan tersebut dilakukan melalui kegiatan, intrakurkuler, kokurikuler dan ekstrakurikuler di dalam sekolah atau madrasah. Selain itu juga dikembangkan di dalam keluarga, dan masyarakat.

Pendidikan seharusnya berorientasi kepada pengenalan realitas diri manusia dan dirinya sendiri. Pengenalan itu tidak cukup hanya bersifat objektif atau bersifat subjektif saja, tetapi harus kedua-duanya. Kebutuhan objektif untuk mengubah keadaan yang tidak manusiawi selalu memerlukan kemampuan subjektif (kesadaran subjektif). Maka dari itu kedua kemampuan ini perlu dilaksanakan secara berbarengan. Tujuan pendidikan Islam pada umumnya untuk mencapai pertumbuhan kepribadian manusia secara

1 Burhanudin Salam, Pengantar Pedagogik (DasarDasar Ilmu Mendidik) (Jakarta: Rineka Cipta, 2000).

2 M Saeidi and M Ajilian, "Rights of Children and Parents in Holy Quran," Farhangi International Journal, 2014, http://eprints.mums.ac.ir/6833/. 
utuh dan seimbang melalui pendidikan jiwa, intelektual, rasional, afektif, dan indera ${ }^{3}$. Oleh karena itu, pendidikan Islam harus mencapai tingkat perkembangan manusia dalam berbagi bidangnya, baik secara spiritual, kecerdasan intelektual, imajinatif, jasmani, ilmiah, kemapuan berbahasa, secara individu maupun kelompok, serta mendorong semua aspek tersebut menjadi baik dan sempur. Tujuan akhir pendidikan Islam terecermin dalam penghambaan yang sempurna kepada Allah swt., baik secara individu, komunitas, maupun seluruh umat manusia.

Ilmu Pendidikan Islam sebagai suatu proses pengembangan potensi kreatifitas peserta didik, bertujuan untuk mewujudkan manusia yang beriman dan bertakwa kepada Allah SWT, cerdas, terampil, memiliki etos kerja yang tinggi, berbudi pekerti luhur, mandiri dan tanggung jawab terhadap dirinya, bangsa negara serta agama. Proses itu sendri sudah berlangsung sepanjang sejarah kehidupan manusia. Ilmu pendidikan islam merupakan prinsip, struktur metodologi, dan objek yang memiliki karakteristik pengembangan ilmu islam ${ }^{4}$. Oleh karena itu pengembangan pendidikan islam adalah upaya memperjuangkan sebuah sistem pendidikan penyelesaian semua problematika kehidupan yang mereka hadapi sehari-hari.

Tujuan utama dari pemahaman Pendidikan Islam adalah pembentukan sikap, perilaku, akhlak dan mentak peserta didik dalam hubungannya dengan tuhan, masyarakat, alam dan semua makhluk. Anak merupakan aset masa depan, anak harus dididik secara benar dengan memperhatikan minat dan bakatnya agar bakat mereka tersalurkan dalam kegiatan yang positif. Cara untuk mendidik anak salah

3 Samhi Muawan Djamal, “Pelaksanaan NilaiNilai Ajaran Islam Dalam Kehidupan Masyarakat Di Desa Garuntungan Kecamatan Kindang Kabupaten Bulukumba," Journal.Uin-Alauddin.Ac.Id 17 (2017), http://journal.uin-alauddin.ac.id/index.php/adabiyah/ article/view/3648.

4 Zakiah Daradjat, Ilmu Pendidikan Islam (Jakarta: Bumi Aksara, 2008). satunya dengan memasukkan anak ke dalam jenjang pendidikan formal atau non formal. Penanaman nilai agama berupa pemahaman dan pelaksanaan ibadah kepada mereka merupakan syarat mutlak untuk mendapat nilai keharmonisan dalam menjalani kehidupan di dunia dan akhirat. Pelaksanaan ibadah harus diajarkan dan dibiasakan. Pelaksanaan tersebut juga harus diiringi dengan penanaman pemahaman peserta didik agar dapat dijadikan pondasi sehingga mereka tidak keluar dari ajaran-ajaran agama ${ }^{5}$. Pada tingkatan sekolah dasar atau Madrasah Ibtidaiyah mata pelajaran Pendidikan Agama Islam diajarkan sejak kelas satu sampai kelas enam. Pelajaran ini berisikan tentang keimanan, akhlak, alqur'an hadits, ibadah dan sejarah kebudayaan Islam. Yang juga di dalamnya menyangkut teori hukum Islam yaitu tentang kewajiban manusia. Khususnya kewajiban individual kepada Allah SWT.

Proses pendidikan adalah suatu proses pengembangan kemampuan dasar atau bakat manusia maka dengan sendirinya proses tersebut akan berjalan sesuai dengan teori perkembangan. Salah satu teori perkembangannya yaitu hukum kesatuan organis, yang menyatakan bahwa perkembangan manusia berjalan secara menyeluruh dalam seluruh organ-organnya, baik organ jasmaninya maupun organ rohaninya, jadi menurut teori ini bahwa perkembangan tidak berdiri sendiri tetapi semua organ berkembang secara bersama. Fungsi kejiwaan manusia berkembang dan berkaitan satu sama lain. Fungsi ini saling mempengaruhi satu dengan yang lainnya. Demikian pula fungsi-fungsi organ tubuhnya. Fungsi-fungsi kejiwaan manusia meliputi antara lain pikiran, kemauan, perasaan, ingatan dan nafsu-nafsu yang senantiasa berkembang secara menyeluruh, tidak terpisah antar yang satu dengan lainnya atau tidak berdiri sendri ${ }^{6}$.

5 Saeidi and Ajilian, "Rights of Children and Parents in Holy Quran."

${ }^{6}$ Martin E. P. Seligman et al., "Positive Education: Positive Psychology and Classroom Interventions," Oxford Review of Education 35, no. 3 (June 2009): 293-311, 
Madrasah sebagai salah satu bentuk pendidikan Islam bertugas membentuk perilaku beragama. Perilaku beragama peserta didik merupakan hasil pembelajaran pendidikan agama di madrasah atau sekolah. Perilaku agama ditunjukkan dengan segala tindakan, perbuatan, dan ucapan yang sesuai dengan norma-norma agama, baik berupa perintah ataupun larangan. Perilaku beragama yang dilakukan tersebut dilaksanakan karena adanya kepercayaan kepada Allah Swt. atas ajaran dan kewajiban-kewajiban sebagai hamba-Nya ${ }^{7}$. Namun pada sisi lain ketika membicarakan mengenai pendidikan pada tingkat dasar lebih banyak dilaksanakan dengan pembiasaan terlebih dahulu baru pemahaman peserta didik. Bahkan terkadang peserta didik belum memahami terhadap ibadah atau ajaran agama yang dilaksanakannya. Hal tersebut seperti penelitian yang menunjukkan bahwa pada jenjang anak prasekolah pembiasaan perilaku ibadah lebih baik dalam membentuk karakter peserta didik daripada daripada pemaknaan terhadap ibadah tersebut ${ }^{8}$. Hal ini menjadi menarik untuk diteliti, bagaimana pemahaman peserta didik pada tingkat dasar tentang pengamalan ibadah yang telah dilakukannya.

Penelitian ini merupakan penelitian kualitatif karena data hasil penelitian lebih berkenaan dengan interprestasi terhadap data yang ditemukan di lapangan 9. Diharapkan terangkat gambaran mengenai kualitas, realitas sosial dan persepsi sasaran penelitian tanpa

\section{https://doi.org/10.1080/03054980902934563.}

7 Sovia Mas Ayu, “Evaluasi Program Praktek Pengamalan Ibadah Di Sekolah Dasar Ar-Raudah Bandar Lampung," Ejournal.Radenintan.Ac.Id 8 (2017), http:// www.ejournal.radenintan.ac.id/index.php/tadzkiyyah/ article/view/2092.

8 Radjasa Radjasa, Sri Sumarni, and Istiningsih Istiningsih, "Developing Character Education Grounded on 'Abk' (Attitude Before Knowledge) Model for Kindergarten at Raudlatul Athfal State Islamic University „,Sunan Kalijaga“ Indonesia," IOSR Journal of Research \& Method in Education (IOSRJRME) 07, no. 01 (2017): 04-11, https://doi.org/10.9790/7388-0701040411.

9 Sugiyono, Metode Penelitian Kuantitatif, Kualitatif Dan RED (Bandung: Alfabeta, 2011). tercemar oleh pengukuran formal. Penelitian didasarkan pada persepsi emik untuk mengungkapkan dan mengurangi sistem dan perilaku bersama satuan strukturnya dan kelompok struktur satuan-satuan itu. Teknik pengumpulan data yang digunakan yaitu wawancara dan observasi yaitu teknik tanya jawab secara langsung atau secara lisan serta pengamatan langsung di MI NU Manafiul Ulum Gebog Kudus.

\section{Metode}

Penelitian ini merupakan penelitian lapangan yang diadakan di MI Manafiul Ulum Gebog Kudus. Analisis data yang digunakan adalah analisis data kualitatif. Data diperoleh melalui proses wawancara dengan kepala sekolah, guru dan peserta didik di madrasah. Selain itu juga diadakan observasi dan dokumentasi. Proses analisis datanya menggunakan langkah-langkah berupa pengumpulan data, reduksi data, penyajian data dan penarikan kesimpulan. Metode berpikir yang digunakan merupakan metode berpikir induktif yang berarti penarikan kesimpulan dari data-data khusus dilapangan ditarik menjadi data yang bersifat umum. Uji keabsahan datanya menggunakan triangulasi.

\section{Hasil dan Pembahasan}

\section{Pengamalan Ibadah Peserta Didik}

Pengamalan berasal dari kata amal yang berarti perbuatan atau pekerjaan, mendapan imbuhan pe-an yang mempunyai arti hal atau perbuatan yang diamalkan ${ }^{10}$. Pengamalan adalah proses perbuatan atau pelaksanaan suatu kegiatan, tugas atau kewajiban. Pengamalan berasal dari kata dasar amal, yang mempunyai arti perbuatan baik yang mendatangkan pahala, sedangkan pengamalan itu sendiri mempunyai arti proses (perbuatan) mengamalkan, melaksanakan, pelaksanaan, penerapan atau proses

10 Poerwadaminta, Kamus Besar Bahasa Indonesia (Jakarta: Balai Pustaka, 2002). 
(perbuatan) menunaikan kewajiban atau tugas 11. Pengamalan dan pengertian ibadah, maka pengertian pengamalan ibadah yakni perbuatan yang dilakukan seorang hamba sebagai usaha menghubungkan dan mendekatkan diri kepada Allah SWT dengan taat melaksanakan segala perintah dan anjurannya serta menjauhi segala larangannya.

Jika kita renungi hakikat ibadah, kita pun yakin bahwa perintah beribadah itu pada hakikatnya berupa peringatan, memperingatkan kita menunaikan kewajiban terhadap Allah yang telah melimpahkan karunia-Nya. Firman Allah swt:

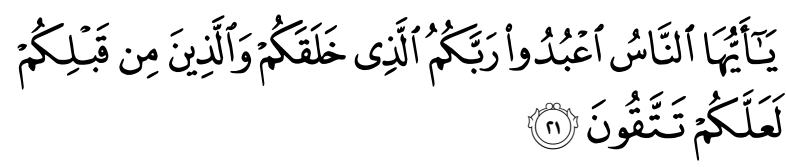

Artinya : "Hai manusia, sembahlah Tuhanmu Yang telah menciptakanmu dan orangorang yang sebelummu, agar kamu bertakwa". (QS. Al Baqarah / 2: 21)

Ibadah mempunyai tujuan pokok dan tujuan tambahan. Tujuan pokoknya adalah menghadapkan diri kepada Allah yang Maha Esa dan mengkonsentrasikan niat kepada-Nya dalam setiap keadaan. Dengan adanya tujuan itu seseorang akan mencapai derajat yang tinggi di akhirat. Sedangkan tujuan tambahan adalah agar terciptanya kemaslahatan diri manusia dan terwujudnya usaha yang baik. Shalat umpamanya, disyari'atkan pada dasarnya bertujuan untuk menundukkan diri kepada Allah SWT dengan ikhlas, mengingatkan diri dengan berzikir. Sedangkan tujuan tambahannya antara lain adalah untuk menghindarkan diri dari perbuatan keji dan munkar ${ }^{12}$.

11 Khoirus Sobirin, "Pemahaman Kitab Fatkhul Mu'in, Pengamalan Thaharah Dan Shalat Fardlu:(Sebuah Penelitian Korelasi Dalam Pendidikan Agama Islam)," Qolamuna 1 (2016), http://ejournal.stismu.ac.id/ojs/index. php/qolamuna/article/download/18/16.

${ }_{12}$ Bayu Prafitri and Subekti, "METODE PEMBINAAN AKHLAK DALAM PENINGKATAN PENGAMALAN IBADAH PESERTA DIDIK DI SMP $\mathrm{N} 4$ SEKAMPUNG LAMPUNG TIMUR," Jurnal. Iain-Padangsidimpuan.Ac.Id 4 (2018), http://jurnal.iainpadangsidimpuan.ac.id/index.php/F/article/view/954.
Upaya-upaya yang dilakukan madrasah dalam membantu peserta didik dalam pengamalan ibadah dapat diketahui melalui wawancara berikut ini: "Sebelum pelajaran dimulai dalam mata pelajaran pendidikan agama Islam dan pelajaran yang lainnya ketika memasuki kelas, semua peserta didik diwajibkan membaca ayat-ayat Al Qur'an (Juz 'Amma) dengan bersama-sama. Hal ini dilakukan agar peserta didik hafal dengan surat-surat pendek dan juga membiasakan peserta didik membaca Al Qur'an tidak hanya di madrasah saja."

Disamping itu melakukan variasi belajar, yaitu dengam mengajak seluruh peserta didik ke Musholla untuk melakukan kegiatan belajar mengajar di Mushalla. Tetapi sebelum melakukan pelajaran saya wajibkan seluruh peserta didik mengerjakan shalat Duha berjama'ah. Sedangkan menurut Guru pendidikan agama Islam $\mathrm{MI} \mathrm{Nu}$ Manafiul Ulum Gebog Kudus berkata bahwa: “Upaya kami selaku guru pendidikan agama Islam, selain melakukan upaya yang ada dalam proses belajar mengajar, kami juga memberikan pembinaan atau program-program kegiatan yang sifatnya keagamaan. Upaya yang dilakukan madrasah, khususnya guru Pendidikan Agama Islam dalam membantu pengamalan ibadah pada peserta didik secara khusus yang dilakukan dalam proses belajar mengajar, juga perlu didukung oleh kegiatankegiatan yang diadakan oleh madrasah.

Kegiatan-kegiatan yang diadakan oleh guru pendidikan agama Islam selaku guru pengajar mata pelajaran pendidikan agama Islam, maupun kegiatan yang diadakan oleh pihak madrasah, diharapkan dapat tertanam dalam masing-masing individu. Sebagai bukti yang kuat dalam pelaksanaan sebagai kegiatan keagamaan sebagai salah satu upaya guru dalam proses pengamalan ibadah pada peserta didik. Hasil dari pengamatan dan wawancara, bahwa guru ternyata tidak hanya mengajar berdasarkan yang ada di dalam 
kelas saja. Akan tetapi keberadaan guru sangat suka begaul dengan para peserta didik ketika jam stirahat. Hal yang dilakukan guru adalah memberikan pemahaman-pemahaman yang berhubungan dengan keagamaan. Contohnya mengulas kembali pelajaran yang telah dipelajari di kelas, memberikan pemahamanpemahaman tentang agama, bercerita tentang kisah-kisah, bahkan guru menerima cerita hati yang kadang-kadang dialami oleh salah satu peserta didik.

Jadi upaya guru dalam membantu peserta didik dalam pengamalan ibadah adalah dengan cara mengadakan pembelajaran yang tidak monoton sehingga dapat menjadikan peserta didik sering bosan. Selain itu guru agama juga tidak hanya memperhatikan peserta didik melalui pelajaran formal yang ada di kelas saja, tetapi juga memperhatikan peserta didiknya ketika dalam keadaan di luar jam pelajaran. Perhatian itu dapat berupa teguran kepada peserta didik jika ada yang berbuat salah, berkumpul dengan peserta didik pada jam Istirahat, dan lain-lain. Ibadah disini yaitu terkait amalan-amalan agama dalam kehidupan sehari-hari.

\section{a. Shalat}

Pengamalan șalat yang dilaksanakan yaitu Salat Dzuhur untuk shalat wajib, Salat Jum'at bagi para peserta didik putera dan $S$ alat Duha untuk Șalat sunnahnya. Pengamalan ini dilakukan dengan cara Şalat Dzuhur ini dilakukan di mushola atau di masjid dekat madrasah sewaktu peserta didik beranjak pulang dari madrasah. Pengawasan dilakukan oleh guru kelas masing-masing dengan rincian untuk Șalat Áshar, Maghrib, İsya dan Subuh dilakukan di rumah dengan kontrol orang tua yang diharapkan mau bekerja sama dengan pihak madrasah, untuk selalu memantau $S$ alat putera-puteri mereka di rumah, yaitu dengan mengisi buku/raport harian yang telah disediakan oleh pihak madrasah. Pembiasaan șalat ini, bagi kelas I minimal 3 waktu, kelas II latihan 5 waktu, kelas III mulai disiplin 5 waktu, dan kelas IV sampai dengan kelas VI mandiri 5 waktu dan diusahakan berjamaah. Sedangkan untuk Șalat Jum'at berlaku bagi para peserta didik putera kelas III-VI.

Salat Jum'at dilakukan di masjid lingkungan tempat tinggal peserta didik di bawah kontrol guru-guru dan orang tua, dengan mengisi laporan ibadah Șalat Jum'at yang di tandatangani oleh imam Șalat jum'at. Kemudian Salat sunnah yang dibiasakan yaitu Șalat Duha dan Tahajud. Șalat Duha ini rutin dilakukan sebelum masuk kelas, dari mulai kelas III sampai kelas VI. Dalam kontrol guru kelas masing-masing. Dalam kesehariannya (diwaktu libur), Șalat Duha ditekankan bagi kelas IV sampai kelas VI. Dengan pengawasan orang tuanya dengan mengisi buku atau raport harian. Guru Pendidikan Agama Islam Ibu Eka Menerangkan bahwa, sebagai tindak lanjut dari program madrasah yaitu menerapkan pembiasaan pengamalan ibadah yaitu pengamalan Șalat, baik itu Ṣalat wajib dan Șalat sunnah itu sangat di tekankan sehingga diperlukan adanya kerja sama antara madrasah dengan wali murid agar tujuan dari pengamalan Șalat itu tercapai. Setiap kegiatan pengamalan di rumah pihak madrasah mengadakan buku ibadah yang nantinya diisi oleh peserta didik dan ditanda tangani oleh orang tua. Untuk Șalat Jum'at keterangan ditanda tangani oleh khatib atau imam Șalat jum'at. Șalat sunnah Duha dilakukan di madrasah bersama-sama sebelum masuk ke kelas.

\section{b. Puasa Ramadhan}

Puasa merupakan salah satu dari pengamalan ibadah yang harus dibiasakan. pembiasaan puasa ramadhan peserta didik dibekali dengan pengetahuan tentang puasa di madrasah dan dalam pelaksanaannya dibantu pengawasannya oleh orang tua peserta didik masing-masing. Pihak madrasah mengontrol melalui melalui buku ibadah yang sudah disediakan oleh madrasah untuk diisi dan diketahui oleh orang tua peserta didik. Untuk pelaksanaan ibadah pada bulan puasa 
lainnya seperti pelaksanaan Șalat taraweh di masjid dengan disertakan tanda tangan imam taraweh.

\section{c. Pembiasaan Doa Harian}

Doa harian yang dibiasakan do'a sebelum memulai dan sesudah pelajaran di kelas, yang dilakukan setiap hari di kelas masing-masing di bawah kontrol guru dan dipimpin oleh beberapa peserta didik secara bergantian, do'a istirahat yang dilakukan sebelum para peserta didik keluar kelas untuk beristirahat, do'a harian sesuai dengan adab yang diajarkan. Do'a harian dilakukan pada peserta didik dikatakan oleh kepala madrasah bahwa do'a merupakan cerminan dari seorang muslim yang memulai segala aktivitasnya dengan mengingat Allah SWT. di madrasah ditekankan pada peserta didik dalam hafalan-hafalan do'a harian agar peserta didik dapat membiasakan segala aktifitasnya dengan berdoa kepada Allah SWT.

\section{d. Pembiasaan Membaca Al-Qur'an}

Tadarus ini dilakukan setiap pagi di kelas masing-masing di bulan ramadhan sesudah doa pembuka di bawah kontrol guru kelas masingmasing. Untuk pembiasaan di rumah, pihak madrasah bekerja sama dengan para orang tua peserta didik untuk memantau aktivitas harian (tilawah Qur'an dan hafalan) putera-puteri mereka di rumah dengan mengisi buku ibadah yang telah disediakan oleh pihak madrasah. Sedangkan di harihari biasa peserta didik melakukan aktivitas membaca dan menyetorkan hafalan Al-Qur'an pada hari jum'at dan sabtu dipandu oleh guru kelas masing-masing. Keterangan oleh guru pendidikan agama Islam bahwa untuk kegiatan tadarus Al-Qur'an itu di lakukan di bulan ramadhan di madrasah pada saat pesanteren kilat yang dipandu oleh guru kelasnya masing-masing. Untuk tadarus di tempat tinggal masing-masing itu dilakukan dibantu oleh kontrol orang tua peserta didik dengan mengisi buku ibadah yang telah disediakan oleh madrasah.

\section{e. Pembiasaan menghafal Al-Qur'an}

MI NU Manafiul ulum merupakan madrasah yang mengutamakan Al-Qur'an di dalam kurikulum khas yaitu diantaranya dalam kegiatan membaca Al-Qur'an binazar dan membaca Al-Quran dengan menghafal. Adapun kegiatan membaca Al-Qur'an pada peserta didik berdasarkan tingkat usia dan tingkat kemampuan peserta didik, untuk peserta didik yang masih duduk di bangku kelas 1 dan kelas 2 khusus diajarkan pada pengenalan huruf hijaiyah dengan makhrajnya dengan baik dan benar. Target dalam membaca Al-Quran yaitu peserta didik mampu membaca Al-Quran dengan baik dan benar menurut kaedah ilmu tajwid. Untuk kegiatan menghafal Al-Quran peserta didik yang di tekankan dalam hal ini yaitu peserta didik kelas 4 sampai dengan kelas 6. Adapun target yang dicapai adalah peserta didik mampu menghafal AlQuran juz amma (juz 30) dari surah Ad-Duha sampai surah An-Nas.

\section{Pemahaman Peserta Didik Tentang Pengamalan Ibadah}

Sikap dan kepribadian seseorang yang telah memiliki pemahaman tentang ajaran agama akan berbeda jika dibandingkan dengan seseorang yang tidak, belum, kurang memiliki pemahaman tentang ajaran agama. perbedaan tersebut akan terlihat dalam sikap dan perbuatannya sehari-hari. seseorang yang telah memahami ajaran agamanya cenderung akan melakukan perbuatan-perbuatan yang diperbolehkan dalam agamanya dan selalu melaksanakan kewajiban-kewajibannya selaku hamba Allah. Orang tersebut juga akan selalu berusaha agar tidak melakukan hal-hal yang dilarang bahkan yang diharamkan oleh agamanya. Kaitannya dengan ibadah, seperti shalat, puasa, dan mengaji, merupakan hal yang diwajibkan dalam ajaran agama Islam yang tidak boleh ditinggalkan oleh setiap Muslim. Kewajiban tersebut harus selalu dilakukan pada waktu-waktu yang telah 
ditentukan. Shalat dilakukan 5 kali dalam sehari semalam, puasa wajib dilakukan ketika memasuki bulan Ramadhan, dan mengaji harus selalu dilakukan setiap harinya.

Bagi anak yang memiliki pemahaman tentang ajaran agama Islam, ia cenderung akan selalu melakukan kewajiban-kewajibannya kepada Allah dengan melaksanakan ibadah secara rutin dan selalu berusaha agar tidak pernah meninggalkan ibadahnya dimanapun ia berada, karena ia menyadari bahwa ibadah yang diwajibkan benar-benar wajib untuk dilaksanakan dan tidak boleh ditinggalkan ${ }^{13}$. Anak melaksanakan ibadah tersebut sematamata untuk memperoleh ridha dan pahala dari Allah. Jika ia meninggalkan ibadah tersebut dengan sengaja, maka ia akan berdosa dan kelak akan mendapatkan ganjaran dari Allah.

Sebaliknya, bagi orang yang tidak atau kurang memiliki pemahaman tentang ajaran agama Islam, ia akan bersikap acuh untuk melaksanakan ibadah yang sebenarnya diwajibkan dalam ajaran Islam. Ia hanya akan melakukan ibadah ketika ada waktu dan kesempatan dan ketika ia mau saja, bahkan bisa saja ia meninggalkan ibadah dengan sengaja untuk melakukan pekerjaan lain. Ia belum betul-betul memahami bahwa ibadah wajib yang ia tinggalkan sebenarnya akan membawa kerugian bagi dirinya sendiri kelak. Tinggi rendahnya tingkat pelaksanaan ibadah seseorang dapat ditentukan dari tinggi rendahnya pemahaman ajaran agama yang dimilikinya.

Walaupun demikian, tidak menutup kemungkinan ada orang yang memiliki pengetahuan agama yang sangat luas bisa meninggalkan ibadah dan bahkan melakukan hal-hal yang dilarang agama. Dimungkinkan ada juga orang yang tidak memahami ibadah yang dilakukannya secara mendalam tetapi

13 Ashif Az Zafi and Firda Falasifah, "Model Pembelajaran Quantum Teaching Pada Mata Pelajaran PAI Di SDN Purworejo 02 Pati," JURNAL AL-QALAM: JURNAL KEPENDIDIKAN 1, no. 1 (January 4, 2019): 1-12. rajin dalam pengamalan ibadah. Menariknya, bagaimana anak-anak pada tingkat sekolah dasar memahami tentang pengamalan ibadah yang mereka kerjakan setelah mendapat pemahaman dan pembiasaan ibadah dari sekolah.

Pemahaman dan pengamalan ibadah dapat dilihat menjadi satu kesatuan ketika melihat beberapa pendapat para ahli pendidikan karakter. Oleh jarena itu perlu melihat bagaimana pendapat mengenai karakter untuk menjawab pemahaman peserta didik tentang pegamalan ibadah yang dilaksanakannya ${ }^{14}$.

Karakter adalah watak,tabiat, akhlak, atau kepribadian seseorang yang terbentuk dari hasil internalisasi berbagai kebajikan (virtues) yang diyakini dan digunakan sebagai landasan untuk cara pandang, berpikir, bersikap, dan bertindak. Karakter diajarkan dengan mengenalkan, memahamkan, hingga mengajak peserta didik sehingga pada akhirnya mereka mampu mempraktikkan dan memaknainya sebagai suatu yang melekat dan menjadi tindakan perenungan (reflective action) serta mengembangkannya menjadi pusat keunggulan insani (center of human excellence). Proses pengembangan nilai-nilai yang menjadi landasan pendidikan karakter, menghendaki suatu proses yang berkelanjutan dilakukan melalui berbagai tema yang diprogramkan ${ }^{15}$.

Jika melihat pengertian tersebut maka seharusnya pemahaman dan pengamalan ibadah seseorang berjalan beriringan. Maksudnya ketika seseorang memahami suatu bentuk ibadah maka ibadah itu juga akan dilaksankan sesuai pemahamannya. Begitu juga sebaliknya, jika seseorang melakukan

${ }^{14}$ Ashif Az Zafi, “Nilai Nasionalisme Kebangsaan Aktivis Rohis," BELAJEA: Jurnal Pendidikan Islam 4, no. 2 (December 3, 2019), https://doi.org/10.29240/belajea. v4i2.861.

${ }_{15}$ Puskur Kemendiknas, Pengembangan Pendidikan Budaya Dan Karakter Bangsa (Jakarta: Kemendiknas, 2010). 
suatu bentuk ibadah berarti orang tersebut paham tentang ibadah yang dilaksanakannya.

Pendidikan karakter menurut Thomas Lickona, adalah pendidikan untuk membentuk kepribadian seorang melalui pendidikan budi pekerti, yang hasilnya terlihat dalam tindakan nyata seseorang, yaitu tingkah laku yang baik, jujur, bertanggung jawab, menghormati hak orang lain, kerja keras, dan sebagainya. Thomas Lickona mengemukakan bahwa karakter terdiri atas tiga bagian yang saling berhubungan yaitu pengetahuan moral, perasaan moral, dan perilaku moral. Ketiga hal tersebut diperlukan untuk mengarahkan suatu kehidupan moral. Dengan adanya tiga bagian tersebut seseorang akan mampu menilai apa yang benar, sangat peduli apa yang benar, dan melakukan apa yang diyakini benar dalam segala kondisi. Berikut diagram yang menunjukkan bagian atau komponen karakter yang baik ${ }^{16}$.

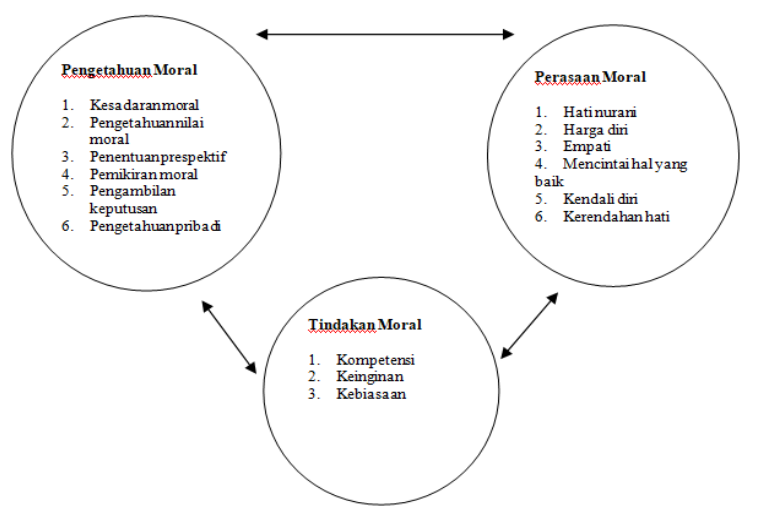

Diagram 1. Komponen Karakter yang Baik

Anak panah pada diagram menunjukkan bahwa masing-masing komponen karakter saling berhubungan. Pengetahuan moral, perasaan moral, dan tindakan moral tidak akan berfungsi sebagai bagian yang terpisah namun saling mempengaruhi satu sama lain dalam cara apapun. Pendapat Thomas Lickona menguatkan asumsi bahwa antar komponen karakter saling mempengaruhi dan berjalan beriringan.

16 Thomas Lickona, Educating for Character (Mendidik Untuk Membangun Karakter) (Jakarta: Bumi Aksara, 2013).
Internalisasi (internalization) diartikan sebagai penggabungan atau penyatuan sikap, standar tingkah laku, pendapat, dan seterusnya di dalam kepribadian ${ }^{17}$. Reber, sebagaimana dikutip Mulyana mengartikan internalisasi sebagai menyatunya nilai dalam diri seseorang, atau dalam bahasa psikologi merupakan penyesuaian keyakinan, nilai, sikap, praktik dan aturan-aturan baku pada diri seseorang ${ }^{18}$. Sedangkan Ihsan memaknai internalisasi sebagai upaya yang dilakukan untuk memasukkan nilai-nilai kedalam jiwa sehingga menjadi miliknya ${ }^{19}$. Pengertian ini mengisyaratkan bahwa pemahaman nilai yang diperoleh harus dapat dipraktikkan dan berimplikasi pada sikap. Internalisasi ini akan bersifat permanen dalam diri seseorang.

Dalam kaitannya dengan nilai, pengertian-pengertian yang diajukan oleh beberapa ahli tersebut pada dasarnya memiliki substansi yang sama. Dengan demikian penulis menyimpulkan bahwa internalisasi sebagai proses penanaman nilai kedalam jiwa seseorang sehingga nilai tersebut tercermin pada sikap dan prilaku yang ditampakkan dalam kehidupan sehari-hari (menyatu dengan pribadi). Suatu nilai yang telah terinternalisasi pada diri seseorang memang dapat diketahui ciri-cirinya dari tingkah laku.

Jika mengacu pada konsep tentang internalisasi nilai maka internalisasi pengamalan ibadah peserta didik melalui beberapa tahapan, yaitu:

\section{a. Tahap transformasi nilai}

Tahap ini merupakan suatu proses yang dilakukan oleh pendidik dalam menginformasikan nilai-nilai yang baik dan yang kurang baik. Pada tahap ini hanya terjadi

17 James P. (James Patrick) Chaplin and Kartini Kartono, Kamus Lengkap Psikologi (Rajawali Pers, 1989).

${ }_{18}$ Rohmat Mulyana, Mengartikulasikan Pendidikan Nilai (Bandung: Alfabeta, 2005).

19 H. Fuad Ihsan, Dasar-Dasar Kependidikan (Penerbit Rineka Cipta, 1997), https://books.google. co.id/books?id=z3rBtQEACAAJ\&dq=Dasar-Dasar+Kep endidikan+fuad\&hl=id\&sa=X\&ved=0ahUKEwiPqJfnnu blAhWBRo8KHTOoCkkQ6AEILDAA. 
komunikasi verbal antara pendidik dan peserta didik ${ }^{20}$. Transformasi nilai ini sifatnya hanya pemindahan pengetahuan dari pendidik ke peserta didiknya. Nilai-nilai yang diberikan masih berada pada ranah kognitif peserta didik dan pengetahuan ini dimungkinkan hilang jika ingatan seseorang tidak kuat. Pada anak usia sekolah dasar yang cara berpikirnya konkret ${ }^{21}$ maka pemberian informasi mengenai ibadah juga harus disesuaikan dengan tahap berpikirnya. Maka dari itu guru memberikan pengertian bahwa ibadah yang dijalankan sifatnya wajib atau sunah, mendapat pahala atau dosa, masuk surga atau neraka. Hal ini sama dengan yang diutarakan oleh peserta didik ketika ditanya mengenai makna dari kegiatan ibadah yang dilaksanakannya. Mereka hanya menjawab bahwa salat lima waktu wajib, mendapat pahala dan dapat masuk surga. Belum terdapat pemaknaan lebih mengenai pengamalan ibadah yang dilaksanakan.

\section{b. Tahap transaksi nilai}

Pada tahap ini pendidikan nilai dilakukan melalui komunikasi dua arah yang terjadi antara pendidik dan peserta didik yang bersifat timbal balik sehingga terjadi proses interaksi ${ }^{22}$. Adanya transaksi nilai pendidik dapat memberikan pengaruh pada siswanya melalui contoh nilai yang telah dijalankan. Di sisi lain siswa akan menentukan nilai yang sesuai dengan dirinya. Jika melihat dari tahap ini, peserta didik pada cenderung untuk menerima nilai yang diajarkan oleh gurunya. Jadi apa yang diajarkan guru dipahami dan dilaksanakan sesuai dengan perkataan guru tersebut. Peserta didik hanya akan menanyakan apabila mereka belum paham mengenai ajaran ibadah yang dilaksanakan.

${ }^{20}$ Muhaimin, Strategi Belajar Mengajar (Surabaya: Citra Media, 1996).

21 JS Benninga, Moral, Character, and Civic Education in the Elementary School. (New York: Teachers College Press, 1991), https://eric.ed.gov/?id=ED396970.

${ }_{22}$ Muhaimin, Strategi Belajar Mengajar.

\section{c. Tahap tran internalisasi}

Tahap ini jauh lebih mendalam dari tahap transaksi. Pada tahap ini bukan hanya dilakukan dengan komunikasi verbal tapi juga sikap mental dan kepribadian. Jadi pada tahap ini komunikasi kepribadian yang berperan aktif ${ }^{23}$. Dalam tahap ini pendidik harus betul-betul memperhatikan sikap dan prilakunya agar tidak bertentangan yang ia berikan kepada peserta didik. Hal ini disebabkan adanya kecenderungan peserta didik untuk meniru apa yang menjadi sikap mental dan kepribadian gurunya. Pada tahap ini peserta didik sudah mampu melaksanakan dan membiasakan pengamalan ibadah yang diberikan oleh guru meskipun terbatas dalam pemahaman. Pemahaman peserta didik hanya sebatas memahami tentang hukum dan imbalan yang diberikan oleh Allah tentang pengamalan ibadahnya. Belum mampu memaknai secara mendalam tentang apa tujuan dan manfaat ibadah bagi kehidupan secara spiritual dan sosial.

Melihat konsep tentang tujuan pembelajaran yang memuat tiga aspek pokok, yaitu: knowing, doing, dan being atau dalam istilah yang umum dikenal aspek kognitif, psikomotor, dan afektif. Internalisasi merupakan pencapaian aspek yang terakhir (being) ${ }^{24}$.Untuk selanjutnya penulis akan memaparkan ketiga aspek tujuan pembelajaran tersebut berkaitan dengan pemahaman dan pengamalan ibadah peserta didik. Pertama, mengetahui (knowing), disini guru telah mengupayakan agar siswa mengetahui suatu konsep. Dalam bidang keagamaan peserta didik diajarkan mengenai pengertian shalat, syarat dan rukun shalat, tata cara shalat, hal-hal yang membatalkan shalat, dan lain sebagainya. Guru menggunakan berbagai metode seperti ceramah tanya jawab dan penugasan. Pemaknaan peserta didik tentang ibadah bukan tentang tujuan dan

${ }^{23}$ Muhaimin

${ }^{24}$ Ahmad Tafsir, FIlsafat Pendidikan Islam: Integrasi Jasmani, Rohani Dan Kalbu Memanusiakan Manusia (Bandung: Remaja Rosdakarya, 2006). 
manfaat pengamalan ibadah yang dilakukan tetapi hanya sebatas mengetahui wajib, sunah, pahala, dosa, surga dan neraka. Jadi pelaksanaan pengamalan ibadah hanya seperti rutinitas yang dilaksanakan tanpa kesadaran dan pemaknaan yang mendalam.

Kedua, mampu melaksanakan atau mengerjakan yang diketahui (doing). Dalam mengajarkan hal ini guru menggunakan metode demonstrasi. Salah satu contoh yang dilakukan Guru yaitu mendemonstrasikan slalat untuk diperlihatkan kepada siswa. Guru juga memutarkan film tentang tata cara shalat selanjutnya siswa secara bergantian mempraktikkan seperti apa yang telah ia lihat di bawah bimbingan guru. Peserta didik sudah mampu untuk melaksanakan ibadah. Ibadah yang dilaksanakan juga sudah menjadi kebiasaan. Pengamalan ibadah sudah berjalan dengan baik berupa salat, puasa Ramadhan, membaca doa harian, membaca dan menghafal Al Quran.

Ketiga, menjadi seperti yang diketahui (being). Konsep ini seharusnya tidak sekedar menjadi milik seseorang tetapi menjadi satu dengan kepribadian orang tersebut. Peserta didik sudah bisa melaksankaan ibadah yang telah dipelajari dalam kehidupan sehari-harinya. Peserta didik telah terbiasa dalam melaksanakan pengamalan ibadah. Ketika ibadah telah melekat menjadi kepriadiannya, maka seorang peserta didik akan berusaha sekuat tenaga untuk menjaga ibadahnya. Namun pelaksanaan ibadah yang sudah menjadi kebiasaannya belum sepenuhnya dihayati dan dimaknai secara spiritual dan sosial.

Berdasarkan pemaparan tersebut dapat dijelaskan bahwa pengamalan ibadah peserta didik pada jenjang pendidikan dasar di MI NU Manafiul Ulum Gebog Kudus sudah menjadi kebiasaan atau being. Peserta didik sudah dapat memahami namun belum bisa memaknai tentang manfaat dan tujuan ibadah secara spiritual dan sosial. Dapat dikatakan bahwa ibadah yang diamalkan oleh peserta didik belum mengkristal menjadi nilai atau perasaan moral.

\section{Kesimpulan}

Proses pembelajaran tentang pengamalan ibadah di MI NU Manafiul Falah Gebog Kudus bermaksud untuk memberikan solusi terhadap kegelisahan orang tua peserta didik tentang praktek keagamaan (ibadah dan akhlak). Ibadah yang diajarkan dan dibiasakan kepada peserta didik adalah salat, puasa, doa harian, membaca dan menghafal Al Quran. Pemahaman peserta didik tentang pengamalan ibadah sudah paham mengenai hukumnya seperti wajib, sunah, dosa, pahala, surga dan neraka. Namun peserta didik belum memahami tentang tujuan dan manfaat ibadah yang dilaksanakannya. Menariknya, pengamalan ibadah peserta didik tergolong taat dan sudah menjadi kebiasaan sehari-hari. Ini menunjukkan bahwa pengamalan ibadah peserta didik sudah menjadi kepribadian (being/tindakan moral) namun masih lemah dalam pemahaman (pengetahuan moral) dan belum mencapai kesadaran (perasaan moral).

\section{Daftar Pustaka}

Ayu, Sovia Mas. "Evaluasi Program Praktek Pengamalan Ibadah Di Sekolah Dasar Ar-Raudah Bandar Lampung." Ejournal. Radenintan.Ac.Id 8 (2017). http://www. ejournal.radenintan.ac.id/index.php/ tadzkiyyah/article/view/2092.

Benninga, JS. Moral, Character, and Civic Education in the Elementary School. New York: Teachers College Press, 1991. https://eric.ed.gov/?id=ED396970.

Chaplin, James P. (James Patrick), and Kartini Kartono. Kamus Lengkap Psikologi. Rajawali Pers, 1989.

Daradjat, Zakiah. Ilmu Pendidikan Islam. Jakarta: Bumi Aksara, 2008.

Djamal, Samhi Muawan. "Pelaksanaan NilaiNilai Ajaran Islam Dalam Kehidupan Masyarakat Di Desa Garuntungan 
Kecamatan Kindang Kabupaten Bulukumba." Journal.Uin-Alauddin. Ac.Id 17 (2017). http://journal.uinalauddin.ac.id/index.php/adabiyah/ article/view/3648.

Ihsan, H. Fuad. Dasar-Dasar Kependidikan. Penerbit Rineka Cipta, 1997. h ttps:// books.google.co.id/ books?id=z3rBtQEACAAJ\&dq=DasarDasar+Kependidikan+fuad\&hl=id\&sa= X\&ved=0ahUKEwiPqJfnnublAhWBRo 8KHTOoCkkQ6AEILDAA.

Lickona, Thomas. Educating for Character (Mendidik Untuk Membangun Karakter). Jakarta: Bumi Aksara, 2013.

Muhaimin. Strategi Belajar Mengajar. Surabaya: Citra Media, 1996.

Mulyana, Rohmat. Mengartikulasikan Pendidikan Nilai. Bandung: Alfabeta, 2005.

Poerwadaminta. Kamus Besar Bahasa Indonesia. Jakarta: Balai Pustaka, 2002.

Prafitri, Bayu, and Subekti. "METODE PEMBINAAN AKHLAK DALAM PENINGKATAN PENGAMALAN IBADAH PESERTA DIDIK DI SMP N 4 SEKAMPUNG LAMPUNG TIMUR." Jurnal.Iain-Padangsidimpuan. Ac.Id 4 (2018). http://jurnal.iainpadangsidimpuan.ac.id/index.php/F/ article/view/954.

Puskur Kemendiknas. Pengembangan Pendidikan Budaya Dan Karakter Bangsa. Jakarta: Kemendiknas, 2010.

Radjasa, Radjasa, Sri Sumarni, and Istiningsih Istiningsih. "Developing Character Education Grounded on 'Abk' (Attitude Before Knowledge) Model for Kindergarten at Raudlatul Athfal State Islamic University "Sunan Kalijaga Indonesia." IOSR Journal of Research $\mathcal{E}$ Method in Education (IOSRJRME) 07, no. 01 (2017): 04-11. https://doi. org/10.9790/7388-0701040411.

Saeidi, M, and M Ajilian. "Rights of Children and Parents in Holy Quran." Farhangi
International Journal, 2014. http://eprints. mums.ac.ir/6833/.

Salam, Burhanudin. Pengantar Pedagogik (DasarDasar Ilmu Mendidik). Jakarta: Rineka Cipta, 2000.

Seligman, Martin E. P., Randal M. Ernst, Jane Gillham, Karen Reivich, and Mark Linkins. "Positive Education: Positive Psychology and Classroom Interventions." Oxford ReviewofEducation 35, no. 3 (June 2009): 293-311. https:// doi.org/10.1080/03054980902934563.

Sobirin, Khoirus. "Pemahaman Kitab Fatkhul Mu'in, Pengamalan Thaharah Dan Shalat Fardlu:(Sebuah Penelitian Korelasi Dalam Pendidikan Agama Islam)." Qolamuna 1 (2016). http:// ejournal.stismu.ac.id/ojs/index.php/ qolamuna/article/download/18/16.

Sugiyono. Metode Penelitian Kuantitatif, Kualitatif Dan RED. Bandung: Alfabeta, 2011.

Tafsir, Ahmad. FIlsafat Pendidikan Islam: Integrasi Jasmani, Rohani Dan Kalbu Memanusiakan Manusia. Bandung: Remaja Rosdakarya, 2006.

Zafi, AshifAz. "Nilai Nasionalisme Kebangsaan Aktivis Rohis." BELAJEA: Jurnal Pendidikan Islam 4, no. 2 (December 3, 2019). https://doi.org/10.29240/belajea. v4i2.861.

Zafi, Ashif Az, and Firda Falasifah. "Model Pembelajaran Quantum Teaching Pada Mata Pelajaran PAI Di SDN Purworejo 02 Pati." JURNAL AL-QALAM: JURNAL KEPENDIDIKAN 1, no. 1 (January 4, 2019): 1-12. 